\title{
A TANYA ÉS A ZÁRT TELEPÜLÉS KAPCSOLATA - TÁRSADALOMFÖLDRAJZI MEGKÖZELÍTÉSBEN
}

\section{DURÓ ANNAMÁRIA}

A II. világháborút követố évtizedek telcpülésformáló folyamatai kényszerpályárá terclték a nagyar tanyarendszert:

1. A nagyüzcmi termelés fokozatos térnyerése megingatta a magánbirtoklásra épülõ tanyás yazdálkodás alapjait. Bár a szocialista mezógazdaság ,,magyar modelljében" a kistermelés is nelyet kapott, a szakszövetkezeti tagok és a háztájin kívül még részes vagy bérelt földet is mũveổ téesz-tagok csupán a magánhasználat elônyeit élvezhetik.

2. A Tanyai Tanács (1949-1951) határozata alapján több mint száz tanyaközpontot jelöltek «i azzal a céllal, hogy zárt településekbe tömörítsék a ,,kintvaló népet” (Orbán 1980). A községhálózat sû́rítése a mezốvárosi tanyarendszerek szétrombolását jelentette.

3. A kültcrülcti ćpitési tilalom még az öncröbôll történơ fejlcsztés lchctốsćgétốl is megfosztota a kinn élôket; a tanyai életforma modernizálása clótt csak a hetvenes évek villamosítási progamja nyitotta meg az utat.

A népszámlálások adatai szerint kétségtelen, hogy 1949 után a külterületi népesség fogyása vált a tanyai átalakulás meghatározó tendenciájává, noha a csökkenés mértékét és ütemét tekintve - regionális léptékben és mikrokörzeteken belül egyaránt - jelentốs területi különbségek apasztalhatók (Beluszky 1983). Míg pl. a Tiszántúlon Szarvas-Békéscsaba, illetve Debrecen śs Nyíregy háza környékét kivéve cz idő alatt mindenütt elổrehaladt a tanyafơlszámolódás folyanata, a Duna-Tisza közi Homokhátságon a korlátozások ellenére is életképesnek bizonyult zz a település- és gazdálkodási rendszer.

A fennmaradás lehetổségei csak településszinten tanulmányozhatók.

Erdei Ferenc számára, valahányszor ,,a tanyát" vette vizsgálat alá, területi és társadalmi zzempontból egyaránt mezôváros és tanyavilága jelentette a kutatás alapegységét (Erdei 1942). Úgy tekintett a tanyák népére mint az adott mezốvárosi társadalom egy területi csoportjára (ErIci 1935).

Az idốközben lezajlott közigazgatási változások átformálták az Alföld településhálózatát: a rajdanvolt mezốvárosok többségének tanyavilága - részben (Kecskemét) vagy teljes egészében Szeged) - új települések, ún. tanyaközségek külterületévé lett. Ezek a tanyás határrészek "kettổs vonzásba” kerültek: múltjuk az egy kori anyavároshoz, jelenük pedig mostani faluközsontjukhoz füzi ổket, így egyiktốl elszakítva sem vizsgálhatók. A magyar tanyát ugyanis éppen 1 zárt településhez fúzổdố különleges kapcsolatok teszik sajátos szórvánnyá.

Hol a hclyük a mai tanyáknak ebben a kapcsolatrendszerben? A szegedi határból önállósult ¡zaty maz és Zákányszék példáján ezt igyekeztem meghatározni. E két, forgalmi helyzetét, töréneti múltját és a helyi szövetkezet típusát tekintve egyaránt különbözố tanyaközség együttes izssgálata többféle tényezô elemzésére nyújtott lehetốséget. 


\section{A társadalomföldrajzi megközelítés lényege}

Lakóhely és munkahely térbeli együttese - a településföldrajz tanyafogalma (Mendöl 1941 nemcsak azért szorul pontosításra, mert az emberi életvitelhez a fentieken kívül más tevékeny ségi körök is hozzátartoznak, hanem azért is, mert a tanya sem mint lakóhely, sem mint munka hely nem a régi már:

1. A mai tanyákhoz nemcsak állandó lakosként lehet kötổdni; léteznek gazdálkodásra vag. hobbicélra használt idôszakosan lakott tanyák is. Ezek csupán ,,tartozékai” az otthonnak, let légyen falubeli, városi vagy akár egy másik tanya lakója a tulajdonosuk.

2. A tanyai gazdaság napjainkban csak a magángazdálkodók és a szakszövetkezeti tagok szá mára jelenti , á munkahelyet", azaz az elsố gazdaság színterét; a többi foglalkozási csopor képviselôi és a nyugdỉjasok - há élnek a kistermelés adta lehetôségekkel - tanyáikon a máso dik gazdaság szereplối.

A , kizárólagos lakóhely" és a , teljes értékú munkahely" funkció elvesztése a zárt település hez való hozzászervezôdés jele. A szocializmus által pusztulásra ítélt, majd, ,átmenetinek" te kintett tanyarendszer tehát mégiscsak beilleszkedik a modernizálódó településhálózatba. D hogyan?

Társadalomföldrajzi megközelítésben új értelmet nyerne a tanyai lét térbelisége.

E szemlélet (irányzat? önálló diszciplina?) képviselôi a helyi társadalom és a településkörnye zet viszonyaként értelmezik az ember- tér kapcsolatrendszert (Berényi 1984). Abból indulnal ki, hogy a finoman rétegzett helyi társadalom egyes csoportjai különbözô térformáló erôve rendelkeznek. Ezek az embercsoportok az ún. társadalmi alapfunkciókon - munka, lakás, el látás, képzés, üdülés, közlekedés-kommunikáció, közösségben élés - keresztül fejtik ki kör nyezetalakító tevékenységüket. A hét alapfunkció gyakorlása meghatározott tér-részletekhez intézményekhez, illetve épített berendezésekhez kötốdik, melyek számára a településkörnyeze ad keretet (Berényi 1983).

Azokat a térbeli összefüggéseket, amelyek a településkörnyezet kialakulása, fejlốdése és je len tértagozódása, valamint a helyi társadalom sajátos térszerkezete között fennállnak, az egye társadalmi alapfunkciók és az azokat mưködtetổ társadalmi csoportok térkapcsolata alapján le het megragadni (i.m. 38.). E térkapcsolatok az emberek életvitellel összefüggố - azaz a lakó helyrốl induló és az adott alapfunkciót hordozó tér-részlet felé tartó - mozgásai útján határoz hatók meg; irányuk térbeli, intenzitásuk pedig idốbeli koordinátákkal jellemezhetổ (Mészáro 1989).

A tanyaközség több szempontból is megfelelổ kerete lehetne ilyen jellegû́ vizsgálódásoknak 1. Már az elnevezés utal arra, hogy ,osztott településrôl" van szó. Ez a települési megosztott ság lehetốvé teszi, hogy az itteni helyi társadalom csoportjai között állandó lakóhelyük térbel elhelyezkedése alapján is különbséget tegyünk, s ennek függvényében elemezzük kapcsolat rendszerüket. Így kiderülne, mit jelent a falu a tanyaiak, s mit jelent a tanya a falubelie életében.

2. A tanyaközségek településközi kapcsolatait szinezi, hogy az a város, amelynek határábć önállósultak, lakóik számảra nem egyszerúen ,,a várost", hanem az egykori ,,anyavárost' jelenti. 
3. A területi összefüggések vizsgálatát teljesebbé tenné, ha a helybeliek tanyaközségen belüli, illetve kifelé irány uló mozgásain túl a ,,második otthonokhoz" (kiskertek és hobbitanyák) kötődô, befelé mutató térkapcsolatokat is föltérképeznénk.

Szatymaz és Zákányszék tanyavilágának kapcsolatrendszerét a két település 1:10 000 méretarányú külterületi térképéből és a helyi tanácsi lakónyilvántartások 1987. évi adataiból kiindulva igyekeztem föltárni. A kinn élốk közül minden hatodik ház lakóit sikerült bevonni a kérdôives adatgyưjitésbe; tanyáik az állandó külterületi lakhelyek 17-17\%-át képviselik. A kérdezettek kiválasztása a családszerkezet típusa (társadalmi szempont) és tanyájuknak a faluközponttól való távolsága (térbeli szempont) alapján történt.

\section{A tanyafejlódés szegedi útja}

Szeged esetében a talajadottságok zonális változására épült a határhasználat övezetes rendszere, a kiskun területek közbeékelődése miatt azonban csak a város körüli feketeföldek alkothattak összefüggőo övezetet, a homoki kaszálók és a külsổ legelôk nem (Juhász 1975). A két nagy határrész elkülönülése a tanyásodás késóbbi menetére is kihatott: Alsótanyát túlnyomórészt a paraszti Alsóváros, Felsốtanyát pedig az iparosok-kereskedők lakta Felsőváros szülöttei népesítették be (Bálint 1976).

A szegedi tanyafejlódést nemcsak a korai kezdetek (Solymosi 1980) és a múvelési ágak harmóniája (Balogh 1965) teszik sajátossá. A helyi földbirtok-politikának köszönhetően a hagyományos városi ház-tanya kétlakiság itt sohasem volt olyan tartós, mint más tanyás városok - pl. Debrecen - esetében. Szeged határában ugyanis városi háztulajdon nélkül is lehetett tanyaföldet szerezni (Juhász 1975), sổt, a múlt században elindított földbérlet-akciók révén maga a város is telepített szórványokat (Barabás 1961; Erdei 1942). Az állandó és teljes kitelepülés megkönnyítette a tanyavilág önállósulását, amely - közigazgatási értelemben - 1949-ben következett be. Alsótanya területén hat, Felsôtanyáén három tanyaközség született. (Üllés, Bordány, Zsombó és Forráskút is ekkor alakult Kiskundorozsma határából. 1. ábra)

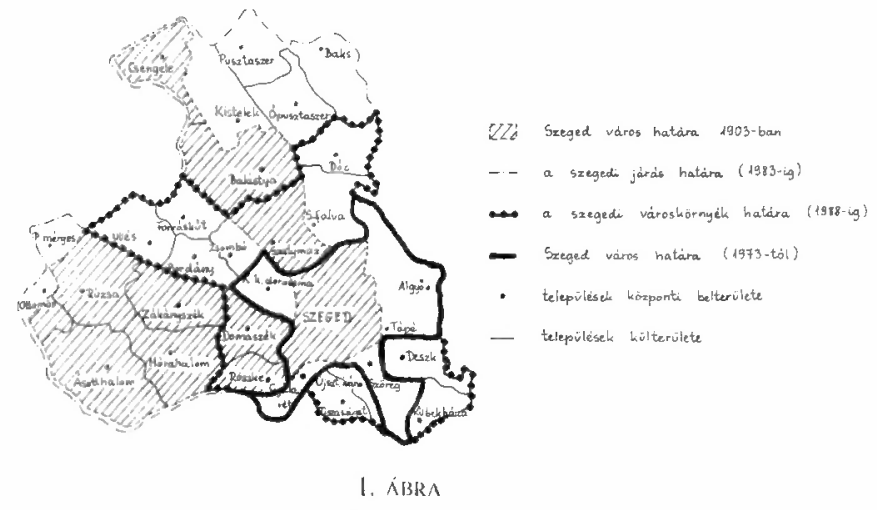

Tanyaközségek a szegedi határban

Csatári B. 1980 nyomán 
A községesítési törekvések sikerét bizonyítja, hogy a szegedi földön kijelölt tanyaközpontok mindegyike életképes faluvá formálódott, sốt, közülük Mórahalom - az egykori Alsóközpont - még a városi rangot is elnyerte (1989). Az ellenhatás erejét mutatja azonban, hogy valamenynyi tanyaközség ,,osztott település” maradt, igaz, olyan ,,osztott település”, amelynek belterülete - lélekszámát és kiterjedését tekintve egyaránt - a külterület rovására gyarapodik.

1. TÁBLÁ'AAT

A szegedi tanyaközségek néhány jellemzó adata

\begin{tabular}{l|c|c|c|c|c|c|c|c|c}
\hline \multirow{2}{*}{\multicolumn{1}{c}{ Település }} & $\begin{array}{c}\text { Területe } \\
\text { (ha) }\end{array}$ & \multicolumn{4}{c|}{$\begin{array}{c}\text { Állandó (jelenlevó) } \\
\text { népesség összesen (fó) }\end{array}$} & \multicolumn{3}{c}{$\begin{array}{c}\text { A külterületen } \\
\text { élók aránya (\%) }\end{array}$} \\
\cline { 2 - 11 } & 1980 & 1949 & 1960 & 1970 & 1980 & 1987 & 1960 & 1970 & 1980 \\
\hline Ásotthalom & 12255 & 8062 & 6542 & 5942 & 4966 & 4271 & 91,5 & 83,5 & 65,0 \\
\hline Balástya & 10995 & 6369 & 5722 & 5238 & 4375 & 3843 & 89,9 & 84,6 & 75,2 \\
\hline Csengele & 6066 & 3680 & 3643 & 3154 & 2707 & 2429 & 90,7 & 85,7 & 73,1 \\
\hline Domaszék & 5214 & 4338 & 3955 & 3574 & 3320 & 3133 & 99,7 & 92,5 & 77,6 \\
\hline Mórahalom & 8314 & 6732 & 6142 & 5859 & 5997 & 5753 & 70,7 & 60,4 & 41,1 \\
\hline Röszke & 3663 & 4227 & 4186 & 3742 & 3517 & 3093 & 41,3 & 42,3 & 29,3 \\
\hline Rúzsa & 8468 & 4469 & 4103 & 3662 & 3182 & 2914 & 92,6 & 87,6 & 76,4 \\
\hline Szatymaz & 5382 & 3897 & 4007 & 4148 & 3781 & 3494 & 88,8 & 79,1 & 69,4 \\
\hline Zákányszćk & 6606 & 3468 & 3393 & 3293 & 3050 & $281 !$ & 90,6 & 84,9 & 68,8 \\
\hline
\end{tabular}

Források: 1. A népszámlálások Csongrád megyei kötetei;

2. Csongrád Megye Statisztikai Évkönyve, 1987.

A statisztikai adatok szintjén csak a koncentráció folyamatát lehet nyomon követni. De mi történt az elhagyott tanyákkal?

\section{A tanyaközponttól a tanyaközségig}

Zákányszék területe Alsótanyához, Szatymazé pedig Felsốtanyához tartozott a községgé alakítások elốtt (l.ábra). Természetföldrajzi szempontból ez nem jelent lényeges eltérést, a forgalmi helyzet tekintetében viszont annál inkább. Felsốtanya ugyanis a vasúti és a közúti közlekedés fốvonalainak irányába esett, Alsótanyát ellenben csak a Város által épített mưút és a kisvasút (1925-1975) kapcsolta Szegedhez.

A két homoki tanyaközség ma is különbözõ lehetốségeket kínál az ott élốk számára, önálló településsé válásuk útja azonban párhuzamba állítható. Ez ,,kettôs elkülönülést” jelent:

1. Kifelé: elkülönülés a szomszédos településektôl. Az új községhatárok addig összetartozó szegedi határrészeket választottak el egymástól és idegen testeket fúztek össze. Szatymaz településrészei - Õszeszék, Külsô- és Belsô-Szatymaz - pl. a maguk életét élték a faluvá szervezés elốtt. Hogy különállásukat máig megốrizték, abban a területükön gazdálkodó három termelôszövetkezetnek is része van. Zákányszék integrálódását megkönnyítette, hogy az ",Egyetértés" szakszövetkezet a tanyaközség egyetlen mezổgazdasági nagyüzeme. 
2. Befelé: a belterület és a külterület elkülönülése. Egyik faluközpont helyét sem újonnan választották meg annak idején; Zákányszék településmagját pl. az 1842-ben emelt , Lengyelkápolna” alkotja (Bálint 1976). 1950-ben, amikor ,,Lengyelbốl” Zákányszék lett, 27 lakóház jelentette a belterületet - ma 436 (1987). Mivel azonban az építkezés csak a lehetôségét teremti meg a beköltözésnek, a belterületen élốk számarányának növekedése sokkal többet mond a faluvá válás útjáról (1. Táblázat).

A belsố népesség-átcsoportosulás egyik községben sem vezetett a tanyavilág drámai elnéptelenedéséhez: a meglévố szatymazi és zákányszéki tanyák kétharmada még mindig állandóan lakott. És fokozatai vannak a lakatlanságnak is (2. Táblázat):

2. TÁBLÁZAT

Tanyatipusok a szatymazi és a zákainyszéki határban

\begin{tabular}{|c|c|c|c|c|}
\hline & \multicolumn{2}{|c|}{ Zákányszék } & \multicolumn{2}{|c|}{ Szatymaz } \\
\hline & $\begin{array}{l}\text { A tanyák } \\
\text { száma }\end{array}$ & $\begin{array}{l}\text { A meglévó tanyák } \\
\text { \%-ában }\end{array}$ & $\begin{array}{l}\text { A tanyák } \\
\text { száma }\end{array}$ & $\begin{array}{l}\text { A meglévó tanyák } \\
\text { \%-ában }\end{array}$ \\
\hline Hiányzó tanyák összesen & 87 & 10,5 & 75 & 7,7 \\
\hline Meglévố tanyák összesen & 831 & 100,0 & 973 & 160,0 \\
\hline I) Állandóan lakott & 563 & 67,7 & 661 & 67,9 \\
\hline Térképen azonosítható & 560 & - & 646 & - \\
\hline A vizsgálatban szerepelt & 96 & - & 110 & - \\
\hline 2) Idôszakosan lakott & 247 & 29,8 & 274 & 28,2 \\
\hline 3) Tanácsi vagy szövetkezeti tulajdon & 8 & 0,9 & 14 & 1,4 \\
\hline $\begin{array}{l}\text { 4) A tulajdonos vagy lakóhelye isme- } \\
\text { retlen }\end{array}$ & 13 & 1,6 & 24 & 2,5 \\
\hline
\end{tabular}

Forrás: A számítások a helyi tanácsi nyilvántartások adatain alapulnak.

1. Kétségtelen, hogy a tanyák egy része a szó szoros értelmében áldozata lett ennek az átrendezôdésnek. Nagyságrendjükre a hiányzó tanyaszámokból, területi elhelyezkedésükre pedig a téesz-táblák, majorok, valamint a két belterület fekvésébôl lehet következtetni.

2. Jóval kevesebb az olyan , tanya”, amely mint épület ma is áll, de nagyüzemi tulajdonban vagy tanácsi kezelésben van. (,Téesz-tanyák", boltok, csárdák, iskolák stb.)

3. Akadnak ugyan romok is, a legtöbb elhagyott tanya mégis idốszakosan lakottá válik. Ezzel csak a hagyományos értelemben vett tanyai életmód folytonossága szakad meg; az ilyen tanyák új szerepkörben élnek tovább.

Erdei Ferenc úgy határozta meg az idốszakosan lakott tanyákat, hogy azok még nem állandóan lakottak (Erdei 1942). Ma viszont éppen fordított a helyzet: ezeknek a tanyáknak már nincsen állandó lakójuk. A , kétfelé való lakás” fóbb változatai (2. ábra) a tanyáról való visszavonulás útjaiként is értelmezhetôk:

"Tanya-tanya" viszonylatban is lehet kettôs életet élni, bár ez még inkább a kötổés, semmint az elszakadás jele. Szatymazon, a téesz-faluban akad rá több példa. Két tanyával rendelkezni ugyanis annyi, mint nagyobb földterületen gazdálkodni. 
Vannak olyan családok, akik a faluba költözés után is megtartják tanyájukat, mert tanya és gazdálkodás számukra ugyanazt jelenti. A külterületen élốk egy része ugyanakkor szintén rendelkezik belterületi házzal - ha nem a saját falujában, a szomszéd települések valamelyikében. (A fölkeresett zákányszéki családoknak 35,4; a szatymaziaknak 15,4\%-a tartozik közéjük.)

Egyazon folyamat, a ,,fokozatos visszavonulás" állomásai ezek. A tanya és a faluközpont közötti kettổs életvitelnek családon belül és generációs váltásban egyaránt többféle változata lehetséges attól függóen, hogy ,,kintról be” vagy ,,bentrốl ki” járnak az emberek.

Ha megszủnik a belsổ utánpótlás, idegenek, fốként szegediek foglalják el a visszavonuló tanyaiak helyét. Hétvégi tanyáik az egykori , ,város- tanya" kettốsség új formáját jelentik. (Elgondolkodtató, hogy mindkét bemutatott tanyaközség esetében ez utóbbi kapcsolódás a legerôsebb.)
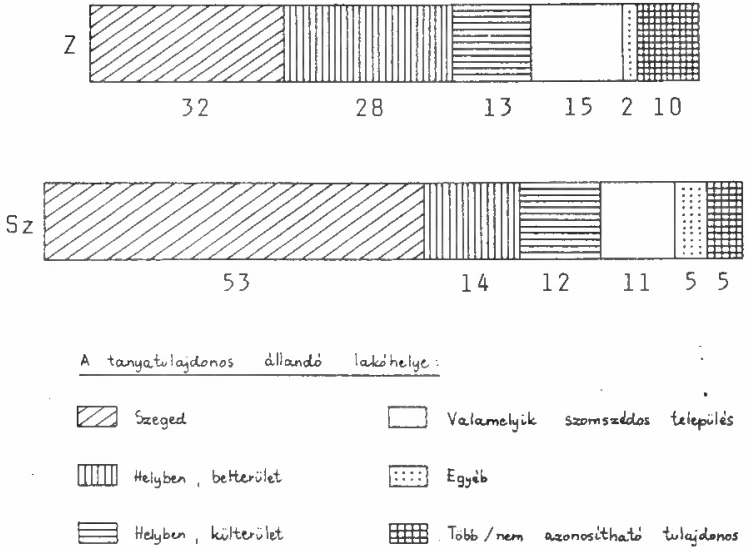

2. ÁBRA

Az idószakosan lakott tanyák \%-os megoszlása tulajdonosaik állandó lakóhelye szerint (Zákányszék esetében 247, Szatymaz esetében 274 tanyát jelent a 100\%)

A mai tanyaközségek külterületén lévố idốszakosan lakott tanyák - amint azt Szatymaz és Zákányszék példája mutatja - nem köthetốk kizárólagos igénnyel sem a faluközponthoz, sem az egykori anyavároshoz; a községhálózat sưrítése a zárt településhez fũzổdổ lakóhelyi kapcsolatok ,,szóródásához" vezetett.

$\mathrm{Az}$ idổszakosan lakott tanyák léte azt bizonyítja, hogy a külterületi népesség fogyása nem föltétlenül azonos a tanyapusztulás mértékével. Tanyáink e csoportja azonban szinte teljesen kívül rekedt a településföldrajzi kutatások körén. Nemcsak azért lenne fontos mielôbb tisztázni a szerepüket, mert jelentôs - és valószínüleg növekvổ - arányt képviselnek, hanem azért is, mert a településhálózati kapcsolódás új elemeit sejthetjük bennük.

\section{A mai tanyák lakói}

Csökkenổ számuk és arányuk ellenére még mindig a tanyaiak al kotják a kiválasztott települések helyi társadalmának legnépesebb csoportját (1. táblázat). A falubeliektổl az különbözteti 
meg ốket, hogy a külterületen van a lakóhelyük, az idổszakosan lakott tanyák tulajdonosaitól pedig az, hogy az év minden szakában kinn élnek.

Különbözố térformáló erôvel rendelkezố csoportjaik - a társadalomföldrajz alapelveit követve - az alábbi szempontok szerint jellemezhetổk. (A külterületen élố családok összetételének, illetve az egyes családtagok életkorának ismeretében bớvíthetố volt a kérdezettek köre. Az elemzés többi része a reprezentatív kérdôívek adataira épül.)

Korösszetétel. Mindkét község tanyáin az 55-65 évesek vannak jelen a legnagyobb arányban, azok tehát, akik közvetlenül 1945 után, az utolsó nagy kirajzási hullám idején alapítottak családot. Gyermekeik jó része is itt maradt, a házasságkötés elốtt álló 15-20 évesek viszont már csak reménybeli utánpótlást jelentenek. Szatymazon különösen szembetûnố a fiatal nốk hiánya.

A hatvan éven felüliek viszonylag kicsiny számaránya a bizonyság arra, hogy a tanyai élet elsốsorban az aktív korúak létformája. Napjainkban azonban egyre rövidül a tanyán töltött életszakasz; a tanyai gazdálkodás mindinkább a gyưjtés eszközévé válik.

Családszerkezet. Korjelzố értékủek az egyes családtípusok is. Míg a magányosak döntổ többsége idôs és a gyermekeiket , ,kiröpített” házaspárok is az öregséghez közelednek, a teljes családokban fiatalok vagy legalábbis aktív korúak élnek. (A hiányos családok nemigen köthetốk életszakaszokhoz.)

A tanyavilág életképességét bizonyítja, hogy mind Szatymaz, mind Zákányszék külterületén a teljes családok vannak többségben ( 35,2 ; illetve $40,3 \%$ ) és közülük minden harmadik többgenerációs.

„Tơsgyökeresek” vagy ,,idegenek”. A születési adatok csak arról tájékoztatnak, hogy kik születtek Szeged mindenkori közigazgatási határán belül és kik idegenben. A hagyományos paraszti rendtôl eltérô - , urbánus" - magatartásformák vizsgálatával azonban a tanya és a zárt település közötti népességmozgás is föltárható.

Ebben a megközelítésben azok tekinthetốk , „tôsgyökeresnek”, akik beleszülettek a tanyai létbe. A tanyára, illetve másik tanyára költözés esetükben a családalapítással függ össze, visszavonulásuk pedig az öregségre való készülődés jele.

A Zákányszékre, illetve Szatymazra települổket (2, illetve 12 család) nem pusztán születési helyük teszi ,,idegenné”; ổk egy más életforma képviselổi. Ezek az emberek ugyanis már meglévổ városi vagy falusi otthonukat adták föl azért, hogy tanyán éljenek. Nem házassági kapcsolat révén kerültek ide; vagy a családalapítást követổ években, vagy gyermekeik ,,kiröpülése" után változtattak lakhelyet. Akár Szegedrõl jöttek, akár messzebbrôl, mindegyiküket a gazdasági lehetôségek vonzották.

Foglalkozás. A mai tanyák vidékünkön sem kizárólag agrárkeresốk lakóhelyei, a foglalkozási átrétegzôdés mértékét és ütemét tekintve azonban jelentôs különbségek mutatkoznak a két település kérdezettjei között. (3. táblázat) Míg a szatymazi aktív keresốk többsége nemcsak a mezốgazdasági alaptevékenységtổ, hanem magától a termelổszövetkezettổl is elszakadt, a zákányszékiek nagy része gazdálkodó szakszövetkezeti tag.

Ez nem magyarázható egyszerũen azzal, hogy a szakszövetkezet jobban meg tudja tartani az embereket, mint a téesz. Az , Egyetértés" ugyanis jóformán az egyetlen gazdálkodó szervezet Zákányszéken, míg a szatymazi termelôszövetkezetek - a gazdagabb helyi munkalehetốségek és Szeged közelsége folytán - ,versenyhelyzetben" vannak. 


\section{TÁBLÁZAT}

A reprezentatív vizsgálatban szerepló tanyai lakosok megoszlása gazdasági aktivitásuk szerint

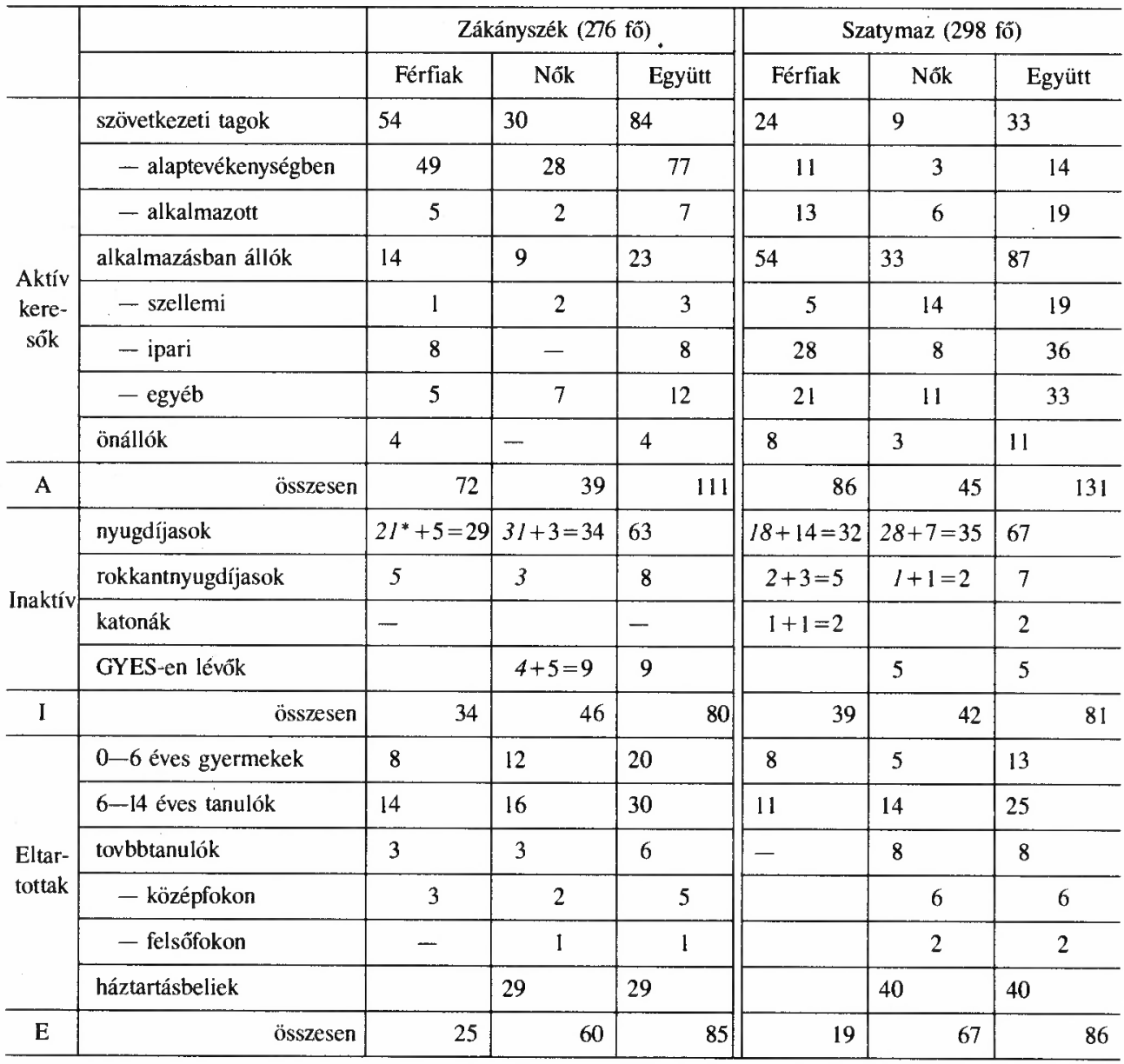

*A dốten szedett számok a szövetkezcti tagokát jelentik.

Iskolázottság. Az idôsebbektól a fiatalabb generációk felé haladva Szatymazon is, Zákányszéken is közel azonos arányban csökken az alapfokú és emelkedik a középfokú végzettségũek részesedése a vizsgálatba vont tanyaiak körében. (Az értelmiséget mindkét helyen betelepült idegenek képviselik.)

A középfokú végzettséget szerzó tanyai fiataloknak valamely szakma tudása, a szakmával rendelkezô mezôgazdasági vállalkozóknak pedig a gazdálkodás lehetôsége adja meg ugyanazt: a , ,két lábon állás” biztonságát. Kizárólag a mezôgazdaságból származó jövedelemre napjainkban nemigen lehet életstratégiát építeni. 
A belterületi ház megléte vagy hiánya. A meginterjúvolt zákányszéki családok közül 40-nek, a szatymaziak közül pedig 23-nak van telke, lakása vagy háza (tanyája) állandó külterületi lakhelyén kívül. Hol? A települések sorrendje - zárójelben az ott ingatlannal bíró családok számával - a következó:

A zákányszékiek esetében:

1. Zákányszék (belterület: 23)

(külterület: 8)

2. Mórahalom (5)

3. Szeged

4. Bordány

5. Domaszék

A szatymaziak esetében:

1. Szatymaz (belterület: 7) (külterület: 3 )

2. Szeged

3. Sándorfalva (4)

4. Zsombó

5. Balástya

Mindkét esetben meghatározó, de nem kizárólagos a faluközpont vonzása; az egykori anyaváros mellett valamennyi környezô község hatása is kimutatható.

Azok a tanyaiak, akik valamely zárt településen is , otthon" vannak, nemcsak a külterületrốl kiindulva vehetnek részt a társadalmi alapfunkciók gyakorlásában.

\section{Hol és milyen tanyában laknak a kinn élók?}

A tanyarendszert annak idején az ésszerư munkaszervezés igénye hívta életre. A lakóház, a gazdasági épületek csoportja és a tanyához tartozó földterület eredetileg egyetlen termelési egységet alkotott.

A reprezentáns szatymazi és zákányszéki tanyák döntő többsége - telepítését és építésmódját tekintve egyaránt - a múlt öröksége. Az egyéni leleménytôl is függött, hogy a korlátozások ellenére hogyan tudtak változtatni ezen az örökségen a külterületen élók. 


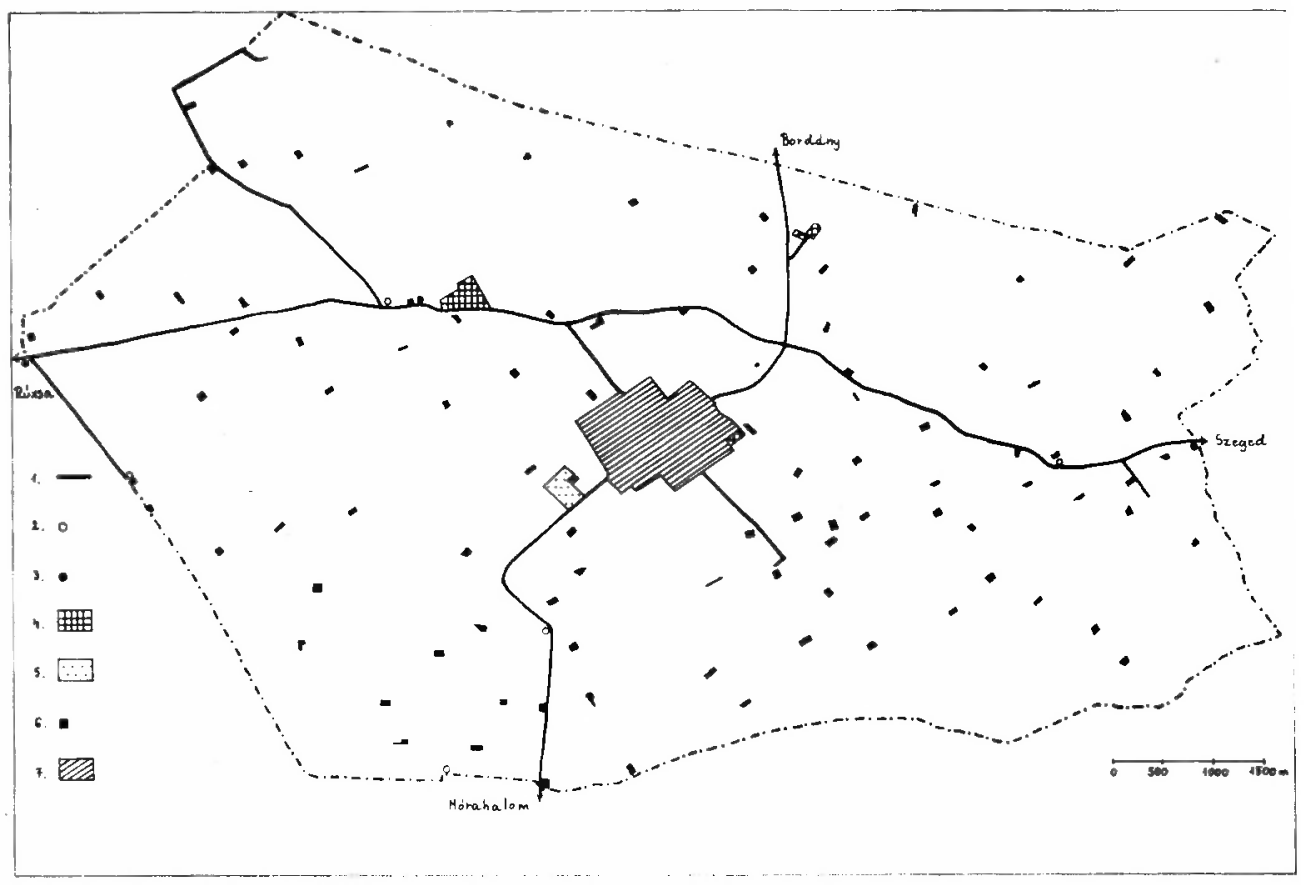

3. ÁBRA

Zákányszék külterületének áttekintố vázlata

1. mưút, 2. volt tanyai iskola, 3. külterületi bolt, 4. a szakszövetkezet központjai, 5. zártkert, 6. a vizsgálatban szereplổ (állandóan lakott) tanya, 7. a tanyaközség belterülete

A természeti adottságok mellett a birtokviszonyok és a mindenkori közlekedésföldrajzi helyzet befolyásolták leginkább a tanyahely megválasztását a régi szegedi határban (Juhász 1974). A földtulajdon-viszonyok átalakítása, a községesítés és az úthálózat kiépülése következtében 1949 után más telepitổ tényezốk váltak fontossá, a tanyarendszer azonban - ,tehetetlensége" folytán - csak a hátrányos helyzetbe kerüló tanyák elnéptelenedése árán igazodhatott ezekhez. (Az idốszakosan lakott tanyák határbéli eloszlását tanulmányozva kiderül, honnan mentek el tömegesen az emberek.)

1949-1986 között csak kivételes esetben lehetett új tanyát emelni: a lakhatatlanná vált régi mellett, vagy - ,újjáépités" címén - annak helyén. Az a néhány lakóépület, amely ilymódon született újjá, a belterületi házak mintáját követi.

Ha a házhelyen változtatni nem is, a tanyaépület minõségén javítani azért mégiscsak lehetett. Akár örökölték, akár vették a tanyát, a legtöbb család kisebb-nagyobb mértékben átalakította azt (alátéglázás, fỏdémcsere, az ereszet befalazása, ,,mozaikozás" stb.).

A külterületi lakóépületek állapota nemcsak az anyagi helyzet, hanem az igényszint tükre is, sốt, olykor még a maradás vagy költözés szándékáról is árulkodik. A szatymaziak és a zá- 
kányszékiek igényességét bizonyítja a villamosított - 95, illetve $90 \%$ - és a fürdôszobával ellátott - 49, illetve $46 \%$ - tanyai lakások magas aránya.

A megváltozott szükségletek új funkciójú gazdasági épületekben is megjelennek. Valószínũleg a tilalmazások következménye, hogy ezek többsége ideiglenes jellegũ építmény (fekete fóliából készült csibenevelô, fóliasátor, garázs stb.).

A mai tanyákhoz tartozó földterület egyes részei nemcsak a mũvelés jellegében - szỏlô, gyümölcsös, szántó stb. - térnek el egymástól, hanem a földhasználat jogalapját illetốen is. A különbözõ földtípusok koncentrálására irányuló törekvés a régi tanyafunkció újjáéledésére mutat.

A $0,5-1$ holdnyi tanyaföld önmagában is több lehetôséget nyújt a kistermelésre, mint a 200-400 négyszögöles falusi porta. Ha ehhez hozzászámítjuk a téesz-tagokat megilletố háztájit és a földbérlet, illetve legelốkiváltás lehetốségét, több holdas kiegészítô gazdaságok múködése sem elképzelhetetlen.

Míg a , ,bentrổ ki” járó gazdák a tanyarendszer lényegének ellentmondó mozgásokra kényszerülnek - reggel ki a határba, este vissza a faluba -, a kinn élók az általuk használt földek és a tanya távolságához mérten alakíthatják ki a termékszerkezetet.

\section{A tanyai életmód térbelisége}

Zákányszék és Szatymaz külterületi lakosai többszörös vonzásban élnek. Hogy mit jelentenek számukra a tanya-faluközpont-város háromszög adta földrajzi keretek, megmutatják azok a térkapcsolatok, amelyeket mint termelốk, mint fogyasztók és mint a rokoni, illetve települési közösség tagjai alakítanak ki. Az emberekéletvitellel összefüggó mozgásainak vizsgálata arra is választ ígért, hogy a különbözổ társadalmi csoportok képviselôi mennyire élnek a tanyai életmód nyújtotta elônyökkel és hogyan tudják legyôzni az abból fakadó hátrányokat. (Mindkét helyen a tanyaiak összessége szempontjából meghatározó mozgásirányok fölvázolására törekedtem; a térkapcsolatok idôbeli koordinátái így szükségképpen háttérbe szorultak.)

\section{Termelés}

Az embereknek dolgozniuk kell valahol, hogy megéljenek, s ki kell használniuk a tanyai gazdálkodás lehetőségeit, hogy jobban éljenek. Az elsố és a második gazdaság szereplổi is, térkapcsolatai is mások.

Az elsố gazdaságban az aktív keresốk vesznek részt. A férfitöbblet mindkét település esetében a háztartásbeli nốk magas arányával magyarázható, ami kifejezetten tanyai sajátosság ( 3 . táblázat).

A foglalkozási összetétel ismeretében nem meglepô, hogy a szatymaziak jelentôs hányada ingázó. (Az alkalmazottak 63\%-a Szegeden dolgozik.) Ezeknek az embereknek naponta át kell lépniük a településhatárokat ahhoz, hogy eljussanak a munkahelyükre. A helyben dolgozók napi munkája - akár a faluközpontba, akár a külterületi téesz-majorok valamelyikébe járnak - településhatáron belüli térkapcsolatokat jelent. A magángazdálkodókat (7fố) nem köti a 


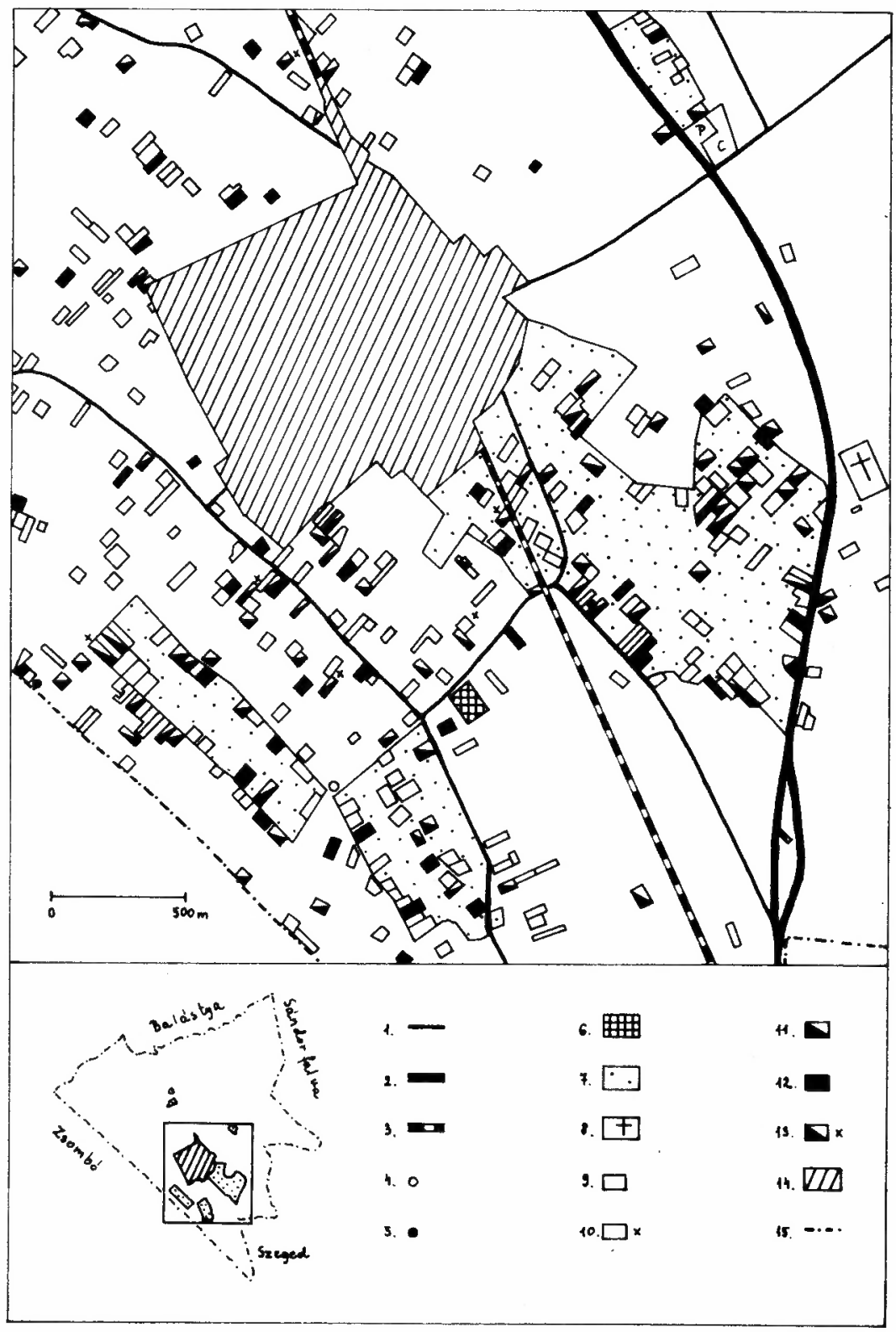

4. ÁBRA

Szatymazi határrészlet (Belsó-Szatymaz)

1. mũút, 2. E-75-ös út, 3. vasút, 4. volt tanyai iskola, 5. külterületi bolt, 6. TSZ-major, 7. zártkert, 8. temetố, 9. állandóan lakott tanya, 10. szövetkezeti tulajdonban lévố tanya, 11. idôszakosan lakott tanya, 12. a vizsgálatban szereplö (állandóan lakott) tanya, 13. a tanyatulajdonos vagy lakóhelye ismeretlen, 14. belterület, 15. településhatár; P: Postakocsi csárda, 
mindennapi munkábajárás kényszere. Számukra már csak azért is lakóhely és munkahely térbeli együttese a tanya, mert a föld, amit mưvelnek, minden esetben a tanya körül helyezkedik el.

Zákányszéken fordított a helyzet: az elsổ gazdaság szereplőinek (3. táblázat) döntố többsége nemhogy a települést, de még a külterületet sem hagyja el napi munkavégzése során. Az aktív keresốk nagy része ugyanis a helyi szakszövetkezet tagja. Ôk a , régi határhasználat elónyét élvezve" (Lettrich 1974, 20.) továbbra is , saját" földjükön gazdálkodnak. , Birtokuk” nagysága és területi elhelyezkedése örökölt feltétel, amin legföljebb földbérlet útján lehet változtatni.

Nem termelố tevékenység ugyan, de a diákok számára mégiscsak munka: a tanulás. Mindkét településre igaz, hogy a határszélen lévổ tanyákról - ha közelebb érik - inkább a szomszéd falu iskolájába (óvodájába) viszik a gyermekeket szüleik.

Míg munkahelyi kapcsolatait mindenki egyénileg alakítja ki, a tanyán folyó kistermelés inkább családi vállalkozásnak tekinthetỗ: az itteni második gazdaságban az inaktív háztartások és az eltartottak is szerephez jutnak.

A termelési feltételeket illetốen a téesz-tagok helyzete a legkedvezôbb. Az alkalmazásban állók lehetôségeit nem annyira a végzett munka jellege, mint inkább a munkahely holléte határozza meg. Az aktív korosztályokat tekintve általában azon családok tanyái a legsivárabbak, ahol mindkét házastárs ingázásra kényszerül. Az öregedổ nyugdíjasok tanyái más okból sivárak: erejük fogytán maguk kénytelenek leépíteni gazdaságukat.

A tanyai gazdálkodás Szatymazon elsốsorban zöldség- és gyümölcstermesztést jelent; az állattenyésztés alárendelt szerepet játszik. A zákányszékiek földmû̉velése viszont részben ma is a jószágtartás szolgálatában áll. A kertkultúra itt csupán kiegészítơje a lehetôség szerint saját takarmánybázisra épülổ tehéntartásnak, bikanevelésnek, illetve szerzôdéses sertéshízlalásnak.

Akár fổ, akár másodlagos jövedelemforrás a tanyai gazdaság, a munkaszervezés és a termelési feltételek biztosítása ma jóval több utánajárást igényel, mint a tanya és a földek közötti kỏzlekedés, azaz a tulajdonképpeni termelés.

\section{Fogyasztás}

Hogy ki hol vásárol s milyen szolgáltatásokkal él a rendelkezésre álló kereteken belül, azt mindenekelổt az igényszint határozza meg. Az emberekben azonban nemcsak a különbözỏ termékek, illetve szolgáltatások iránti igény él, hanem az a törekvés is, hogy lakóhelyükrốl kiindulva egy számukra elfogadható méretư térségen belül ki is elégíthessék ezeket az igényeket.

Kinek mit jelent ez az elfogadható méretû̃ térség - a tanyai lakóhelyrốl nézve? A fogyasztás térkapcsolatait a személyes szükségletek néhány meghatározó eleméból kiindulva igyekeztem fölvázolni.

Élelmiszer-ellátás. Bár az alapvetố élelmiszereket a külterületen is meg lehet venni, a tanyai boltok kínálatával rendszerint csak a helyhez kötött környékbeli öregek érik be; szinte mindenki a faluközpontban vásárol. A mórahalmi, illetve sándorfalvi határrész lakói is ezt teszik, csak éppen a , szomszédban”'. (Mindkét kiválasztott tanyaközség kérdezettjei között akad 10-12 család, akik a bevásárlástól az orvosi vizsgálatig szinte mindent itt intéznek. Sándorfalva vonzerejét növeli, hogy belterülete közvetlenül határos Szatymaz tanyavilágával.) Az ingázók Szegeden is megejthetik a napi bevásárlást. 
Az aktív korosztályok általában elég ,,mozgalmas” életet élnek, így nagyobb esélyük van arra, hogy más intéznivalóval kössék össze vásárlásaikat. A tanyai öregek viszont jóformán csak ezért mozdulnak ki otthonról. Aki nem tudja számára elérhetổ közelségben kielégíteni élelmiszer-szükségletét, különbözõ ,,beszerzési stratégiákat" kénytelen alkalmazni.

Egészségügyi ellátás. A falubeli körzeti orvos fölkeresése rendszerint csak az elsõ állomása a gyógykezelésnek; a fogászat és a gyermekorvosi ügyelet kivételével ugyanis valamennyi szakrendelés a városba szólítja az embereket. (Az ágyhoz, illetve ,, házhoz” kötött öregekhez hívás nélkül is kijár az orvos.)

Fodrász. Van, aki szerint az asszonyok száz kilométerrôl is visszajárnak kedves fodrászukhoz. Ha túlzás is ez a megállapítás, a lényeget magában foglalja: a fodrászhoz járás rendszeres kapcsolattartást föltételez és sokkal inkább szabad választáson alapul, mint a fogyasztás eddig vázolt térkapcsolatai. Újabb szál, amely a zárt településhez füzi a tanyaiakat; a férfiakat is. De melyikhez? Mindkét község esetében azonos a sorrend: 1. Szatymaz (Zákányszék), 2. Szeged, 3. Sándorfalva (Mórahalom).

Szórakozás. Alkalmai is, színterei is változnak az életkorral. Nem vitás, hogy a családalapítás elôtt álló fiatalok a legaktívabbak. A szatymaziak nem mind érik be a helyi diszkóval; gyakori, hogy többen összefogva kocsival járják végig a környezô községek szórakozóhelyeit. Az aktív korú tanyaiakat általában eléggé leköti a gazdaság; ahol jószágot tartanak, hosszabb idốre nem is nagyon mozdulhat ki a család. Az idôseknek az is szórakozás, ha nézik a TV-t.

A fogyasztás szempontjából ma kétségtelenül hátrány tanyán lakni. A gazdálkodó aktív korúakat a mezôgazdaságból származójövedelem kárpótolja a nehézségekért - végső soron ez teszi lehetôvé a belterületi ház fölépítését is -, a kinn éló öregek azonban csak a hátrányait érzik a tanyán való lakásnak. Szatymazi példák szerint újabban a kertvárosi életforma is kínálhat olyan elônyöket, amelyekért érdemes tanyára költözni.

\section{Közösségben élés}

Ezeket a térkapcsolatokat nagyon is emberi szükséglet: az összetartozás igénye hívja életre. A rokoni, baráti találkozások nem korlátozódnak az ünnepekre - a munkától a bevásárlásig megannyi alkalmat ad rá a mindennapi élet.

Rokonság, család. A szatymaziakat és a zákányszékieket egyaránt saját településükhöz fũzik a legerôsebb vérségi kötelékek; az egykori anyaváros csak a második helyen áll. Szomszédaik közül a Nagyárvíz (1879) után telepített Sándorfalva és szegedi tanyaközségek emelkednek ki. „,Rokoni alapon” is bizonyítható tehát, hogy a néhai ,,dorozsmai főd” határai valóban történeti határok (1. ábra).

Annak ellenére, hogy a rokonság nagy része helyben vagy legalábbis elérhetô közelségben él, nem rendszeres a kapcsolattartás. Az esztendős ünnepek közül még leginkább a karácsony, a családiak közül pedig a névnapköszöntés jelent ilyen alkalmat. A nagy családi összejövetelek ideje elmúlt, a szúkebb család viszont általában összetart.

A falusi búcsú - lett légyen akár helyben, akár a szomszéd községek valamelyikében nem mindennapi alkalom a találkozásra. Rendszerint családi ebéddel kötik össze. Aligha véletlen, hogy a szatymazi , ,úcsújárók” saját falujukon kívül Sándorfalvát, Balástyát és Zsombót, 
a zákányszékiek pedig Rúzsất, ,,Mórât”, Bordányt, Üllést és Domaszéket keresik föl legnagyobb arányban.

Települési közösségek. Tanyán különleges értéke van a - jó - szomszédságnak: ,„Valami segítség köll, ezöknek adunk, ezöktốl kapunk. Ha baj van, ezt érjük legelébb”'(Zákányszék). A ,,tôsgyökeres" tanyaiak rendszerint együttmúködnek az élet minden területén. A tanyára települổ ,,idegenek” általában beépülnek ebbe a ,,szomszédsági hálóba”, ám a falu közösségébe szinte sohasem. Bizonyos értelemben a hétvégi tanya-tulajdonosokat és a kiskerteseket is szomszédnak tekintik a külterületen élốk, de - paraszti mentalitás szerint - ôket is a munkájuk alapjân ítélik meg.

A helybeliek szemében már csak azért sincs nagy különbség tanyai és falusi között, mert kettốs ingatlantulajdonnal rendelkezô ,,bejáró" tanyaiak éppúgy vannak, mint ,,kijáró” falusiak. A tanyaiak döntố többsége is a faluhoz tartónak vallja magát, bár vannak ellenvélemények. A városból kitelepülốk pl. továbbra is Szegedhez vonzódnak. Akiket a szomszéd települések valamelyike ,csábít el", kivétel nélkül a határszélen laknak. A ,,sehova se tartozók” a kirekesztettséget panaszolják föl, mondván: ,,Mostoha embörök vagyunk" (Szatymaz). Csak kevesen vállalják tudatosan azt, hogy ,tanyasiak".

Az új községek határai közé zárt tanyavilág lakói - hacsak a munkahely nem köti ôket idegenek már Szegeden. Nem azért kelnek útra, hogy egy városi közösség tagjainak érezzék magukat; céljaik nagyon is kézzelfoghatóak: piacozás, bevásárlás, orvosi vizsgálat, rokonlátogatás. Nem véletlen, hogy a , tốsgyökeres" tanyai nép számára a piac és a buszállomás környéke a legbiztosabb támpont. Természetesen egészen más ,,Szeged-képe” van annak, aki korábban itt lakott, tanult, dolgozott vagy most is bejár nap mint nap.

Jelképes értelmũ, hogy Zákány-Alsón - a faluközpont és a város közötti határrészt hívják így - a falu felé igyekezvén ma is azt mondják: , Kimögyünk a faluba”. A befelé az Szeged felé van ...

\section{Összegzés}

\section{A ZÁRT TELEPÜLÉS}

A kijelölt tanyaközpontok faluvá formálódásával gyökeresen megváltozott a tanyák településkörnyezete: új zárt települések születtek a mezôvárosi tanyarendszerek területén.

\section{A TANYA}

A mai tanyaközségek külterületén lévổ tanyák egy része állandóan, más része idôszakosan lakott. Külterületi lakosnak csak azok tekinthetốk, akik számára a tanya ,,az otthont” jelenti. A tanyaiak ilymódon az adott helyi társadalom egy, az állandó lakóhely térbeli elhelyezkedése alapján kiemelt csoportját képviselik. 


\section{KAPCSOLATUK}

A megváltozott településkörnyezetből kiindulva kezdtem keresni azokat a szálakat, amelyek a mai tanyákat mostani faluközpontjukhoz, egykori anyavárosukhoz, valamint a szomszédos településekhez füzik. Társadalomföldrajzi megközelítésben e ,,szálak” azokkal a térkapcsola. tokkal azonosíthatók, amelyeket a tanyaiak az egyes társadalmi alapfunkciók gyakorlása sorár alakítanak ki.

A két szegedi tanyaközség példáján a lakófunkció, valamint a termelés, a fogyasztás és a kö. zösségben élés legfontosabb területi összefüggéseit igyekeztem föltárni.

A lakást az teszi különlegessé a társadalmi alapfunkciók sorában, hogy mint az eletvitelle. kapcsolatos mozgások kezdô- és végpontja, megteremti a feltételeket a többi alapfunkció gya. korlásához.

A szatymazi és a zákányszéki példa szerint a tanyaközségek helyi társadalma nem oszthatć föl egyszerüen tanyaiakra és falusiakra, mert kettốs ingatlantulajdonnal rendelkezố ,,kintrố] be" járók éppúgy laknak itt, mint ,,bentrôl ki” járók. A , ,kétfelé való lakás” különbözố változa. tai azt sejtetik, hogy a részekre szabdalt tanyavilág ugyanolyan módon szerveződik hozzá kijelölt központjaihoz, mint amilyen kapcsolatban kialakulása idején magával az anyavárossal volt. Lényeges különbség azonban, hogy a tanyaközségek esetében nem a kirajzás, hanem a betele. pülés a meghatározó népesedési folyamat.

Nemcsak külterület-belterület viszonylatban létezik ilyen lakóhelyi kapcsolódás; arányeltolódásokkal bár, de kimutatható a tanya és az egykori anyaváros, valamint a tanya és az egyes szomszédos faluközpontok viszonylatában is.

A termelés térkapcsolatait a megélhetés kényszere tartja fönn; ezek a leginkább meghatározottak.

Az elsố gazdaság jellegadó térkapcsolatai Szatymazon átlépik a településhatárokat (Szegedre ingázó al kalmazottak), Zákányszéken ellenben azon belül maradnak (helyben dolgozó szakszövetkezeti tagok).

A második gazdaság térkapcsolatai a tanyai gazdálkodáshoz kötổnnek:

Szûkebb értelemben: a tanya és a földek közötti közlekedés.

Tágabb értelemben: mindaz az utánajárás, amit a gazdaság fönntartása megkövetel.

A fogyasztás térkapcsolataiban az igényszint a meghatározó. Társadalmi különbségek fejezódnek ki abban, hogy kiknek jelent meghatározó életkeretet a tanya (helyhez kötött öregek), a falu (, ,tôsgyökeres" aktív korúak), a város (, ,idegenek"), s kik azok, akik áttörik a tanya-faluközpont-város háromszög kereteit (piacozó mezôgazdasági vállalkozók).

A közösségben élés spontán térkapcsolatai vallanak legtöbbet a tanya-tanya, tanya-faluközpont, illetve a tanya-város viszonyról.

A mai tanyák lakói vagy elfordultak az anyavárostól s a faluhoz tartozónak vallják magukat (, ,tôsgyökeresek"), vagy új módon - munkahelyük, illetve korábbi lakóhelyük révén - kötốdnek Szegedhez (ingázók, ,,idegenek”).

Az emberi kapcsolatok abban is meghatározó szerepet játszanak, hogy a tanyaiak hol fognak belterületi építkezésbe, azaz mely település közösségéhez kívánnak tartozni.

Akár a termelést, akár a fogyasztást vagy a közösségi létet tekintjük, a határszélen élőket szinte mindegyik tevékenységi kör a szomszéd települések valamelyikéhez fúzi. Mindkét tanya- 
község esetében a hagyományos kapcsolatok a legerôsebbek: a zákányszékiek Mórahalomhoz (a néhai Alsóközpont), a szatymaziak pedig Sándorfalvához (egykor̃ a Pallavicini-uradalom központja) vonzódnak leginkább. Ezek a térkapcsolatok bizonyos értelemben újrarajzolják a településhatárokat.

\section{Irodalom}

Balogh I. (1965) Az alfóldi tanyás gazdálkodás. In: A parasztság Magyarországon a kapitalizmus korában 1848-1914 (I. Szerk.: Szabó I.) Budapest: Akadémiai Kiadó: 429-479.

Barabás J. (1961) A szórványtelepülések kialakulása Közép-Európában. In: Müveltség és hagyomány (Szerk.: Gunda B.) Budapest: TK: $219-247$.

Bálint S. (1976) A szögedi nemzet I. A Móra Ferenc Múzeum Évkönyve 1974-1975/2. Szeged.

Becsei J. (1977) Az agrárvárosok átalakulásának néhány jellegzetessége. Alföldi Tanulmányok I. Békéscsaba: 96-116.

Beluszky P. (1973) A tanyarendszer idôszerũ problémái. A tanyafelszámolódás folyamata. Földrajzi Közlemények, XXI. évf. 1: 19-36.

Beluszky P. (1983) A tanyaátalakulás jellemzỡ folyamatai az elmúlt évtizedekben. In: Társadalmi-gazdasági változások és telepulésstruktúránk fejlơdése. (Szerk.: Dövényi Z. - Tóth J.) Békéscsaba: 81-96.

Berényi I. (1983) A településkörnyezet társadalomföldrajzi vizsgálata. Földrajzi Értesító XXXII. évf. 1: 37-47.

Berényi I. (1984) A településkörnyezet társadalomföldrajzi vizsgálatának fốbb vonásai. In: Az Alfóld gazdaságföldrajzi kutatásának fóbb eredményei és további feladatai (IV. Népesség és település. Szerk.: Timár J. - Tóth J.) Békéscsaba: $102-108$.

Csatári B. (1980) A szegedi járás tanyarendszerének néhány jellegzetessége. Alföldi Tanulmányok IV. Békéscsaba: $85-106$.

Dénes I. Z. (1980) A paraszti polgárosodás modellje. Erdei Ferenc tanyafelfogásának alakulása. In: A magyar tanyarendszer múltja (Szzerk.: Pölöskei F. - Szabad Gy.) Budapest: Akadémiai Kiadó: 313-338.

Duró A. (1989) A tanyai átalakulás társadalomföldrajzi vonatkozásai Szatymaz és Zákănyszék példáján. Egyetemi doktori értekezés. Kézirat. József Attila Tudományegyetem, Szeged, 130 o.

Erdei F. (1935) Területi csoportok egy mezốváros társadalmában. Adalékok Makó társadalomrajzához. Népünk és nyelvink 7-12: 244-252.

Erdei F. (1941) A tanyás települések földrajzi szemlélete. Földrajzi Közlemények LXIX évf. 2. 103-113.

Erdei F. (1942) Magyar tanyák. Reprint. Budapest: Akadémiai Kiadó, 1976.

Harcsa I. (1984) Mezôgazdasági kistermelés, életkörülmények, életmód. Társadalomkutatás 3-4: 134-153.

Juhász A. (1974) Telekelrendezés a szegedi tanyákon. Ethnographia LXXXV. évf. 2-3: 276-314.

Juhász A. (1975) Adatok a szegedi tanyák kjalakulásához. Ethnographia LXXXVI. évf. 2-3: 176-312.

Kósa L. (1984) Hagyomány és közösség (Magyar népi kultúra és társadalom) Budapest: Kozmosz Könyvek.

Lettrich E. (1968) Az Alföld tanyai település- és gazdálkodásY rendszere. Földrajzi Közlemények XVI. évf. 1: 21-39.

Lettrich E. (1974) Tanyahálózatunk mai fố vonásai és azok regionális különbségei. In: Paraszti társadalom és müveltség a 18-20. században. III. Tanyák. Szolnok: 11-26.

Mendöl T. (1941) Megjegyzések Erdei Ferenc ,,A tanyás települések földrajzi szemlélete” c. cikkéhez. Földrajzi Közlemények LXIX. évf. 2: 113-115.

Mészáros R. (1988) A falusi település térbelisége a lakosság a térpályái alapján. Tér és Társadalom 2. évf. 1: 43-57.

Mészáros R. (1989) A térkapcsolatok értelmezésének néhány összefüggése. Tér és Társadalom 3. évf. 1: 3-16.

Orbán S. (1980) Tanyaközpontosítási, községesítési kísérletek a felszabadulás után. In: A magyar tanyarendszer múltja. Budapest: Akadémiai Kiadó: 362-398.

Petri E. (1966) Szarvas és környéke tanyás településrendszerének mai települési problémái. Fơldrajzi Értesitố XV. évf. 3: $347-370$.

Solymosi L. (1980) A tanyarendszer középkori elốzményeinek historiográfiája. In: A magyar tanyarendszer múltja. Budapest: Akadémiai Kiadó: 71-96. 
Tér és Társadalom 4 . 1990-2: 63-80.

\section{RELATIONSHIPS BETWEEN SCATTERED FARMSTEADS (TANYA) AND CORE SETTLEMENTS A Social Geographical Approach ANNAMÁRIA DURÓ}

The specific feature of the Hungarian scattered farmstead (tanya) is derived from its peculiar relationship with the core settlement, the so called parent town. The 1949 local administration reform modified this very relationship: as a result of the formation of designated scatteredfarmstead-centres into central villages, new core settlements were established on the territory of scattered farmstead areas in rural-market-town regions. But the hoped rapid liquidation of tanyas was not happening: villages with scattered farmsteads remained , divided settlements", though with their inner areas increasing-both in population number and extent-to the detriment of outer areas.

Taking this modified relationship as a starting point, the author seeks the connecting links between present scattered farmsteads and their central village, the former parent town, or neighbouring settlements. In a social geographical approach, these links are identified as spatial relationships developed by tanya inhabitants while exercising basic social functions.

Thanks to a research grant, the author could study tanyas in the outer areas of two villages in a sandy region-from a social geographical point of view. The paper summarizes the major results of this field study, highlighting four elements out of the system of basic social functions: the spatial links of housing, production, consumption and social life.

Transl. E. Daróczi 


\section{DURÓ ANNAMÁRIA TANYAKÉPEI 1988-1989}

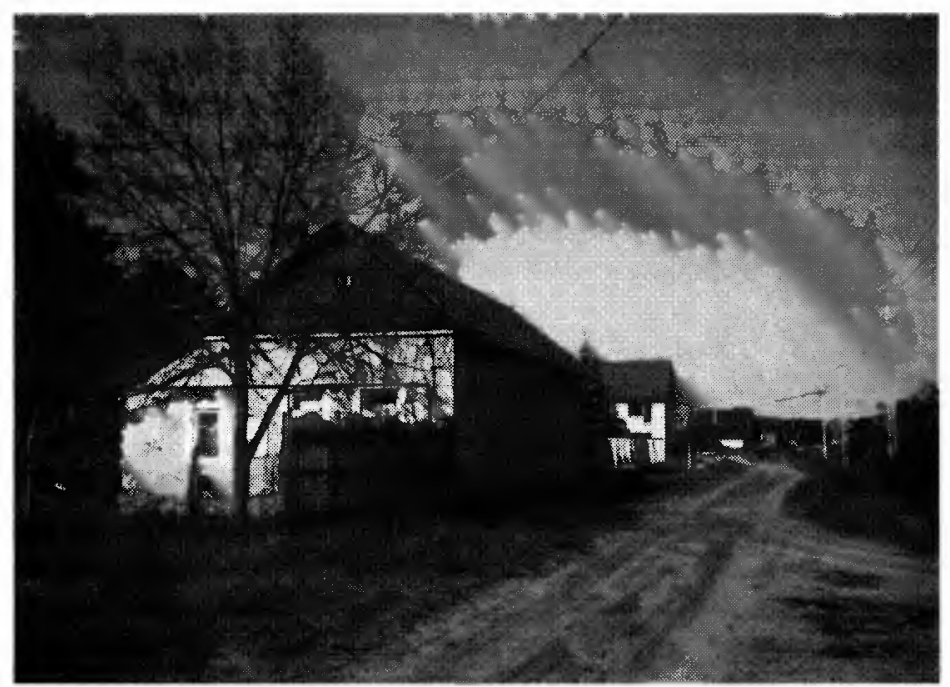

1. KÉP

Belterületté nyilvánított tanyaépület Szatymazon. Tajolása szemmel láthatóan eltér az út mentén sorakozó új házakétól.

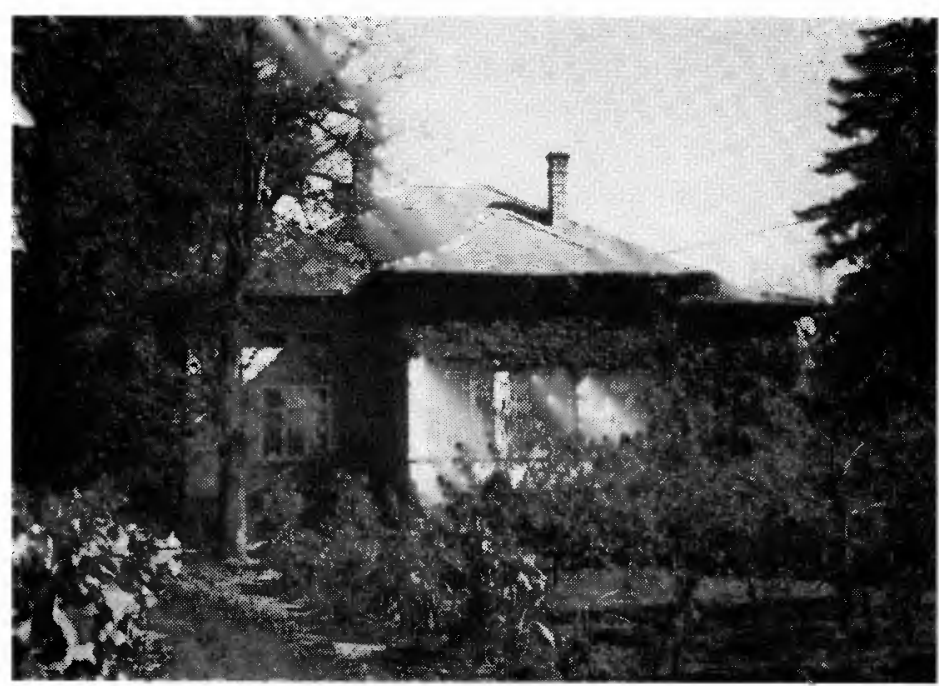

2. KÉP

A szatymazi tanyavilág képéhez az úri nyaralók is hozzátartoznak. Ez a jánosszállási villa az 1930-as évekból való. 
A tanya és a zárt települések kapcsolata - társadalomföldrajzi megközelítésben.

Tér és Társadalom, 4. 1990. 2. 63-85. p.

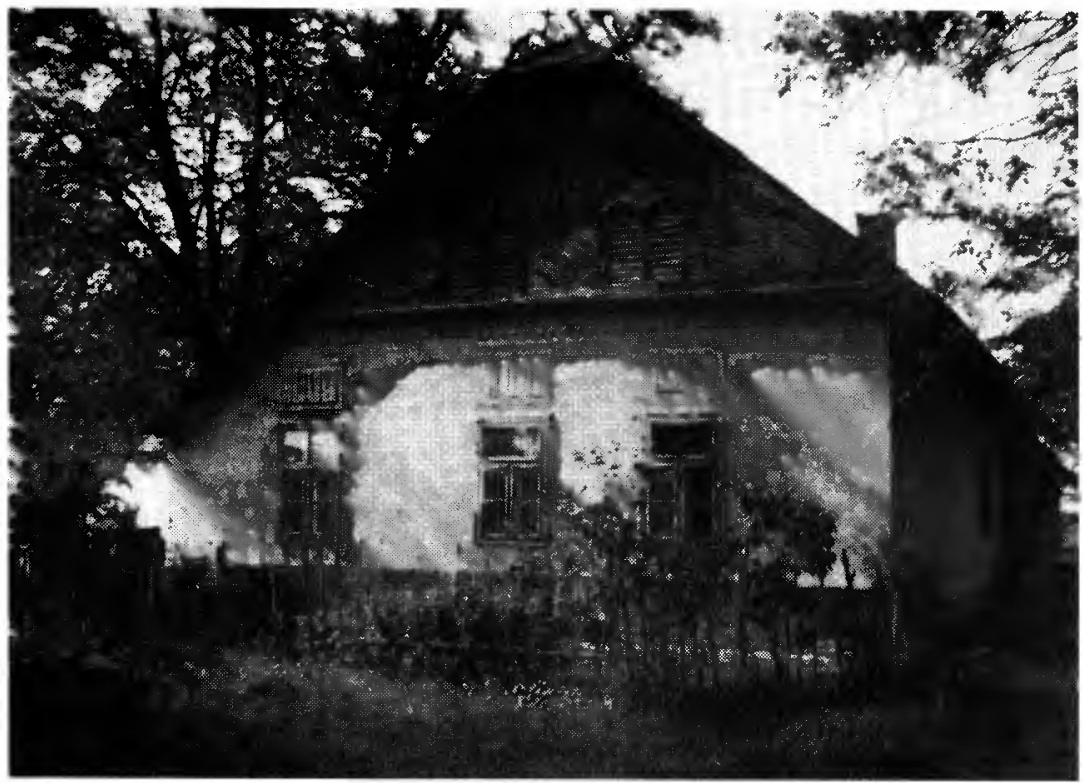

3. KÉP

A szegedi tájra egykor oly jellemzô napsugaras házvéget tanyán csak elvétve látni már (Zá kányszék).

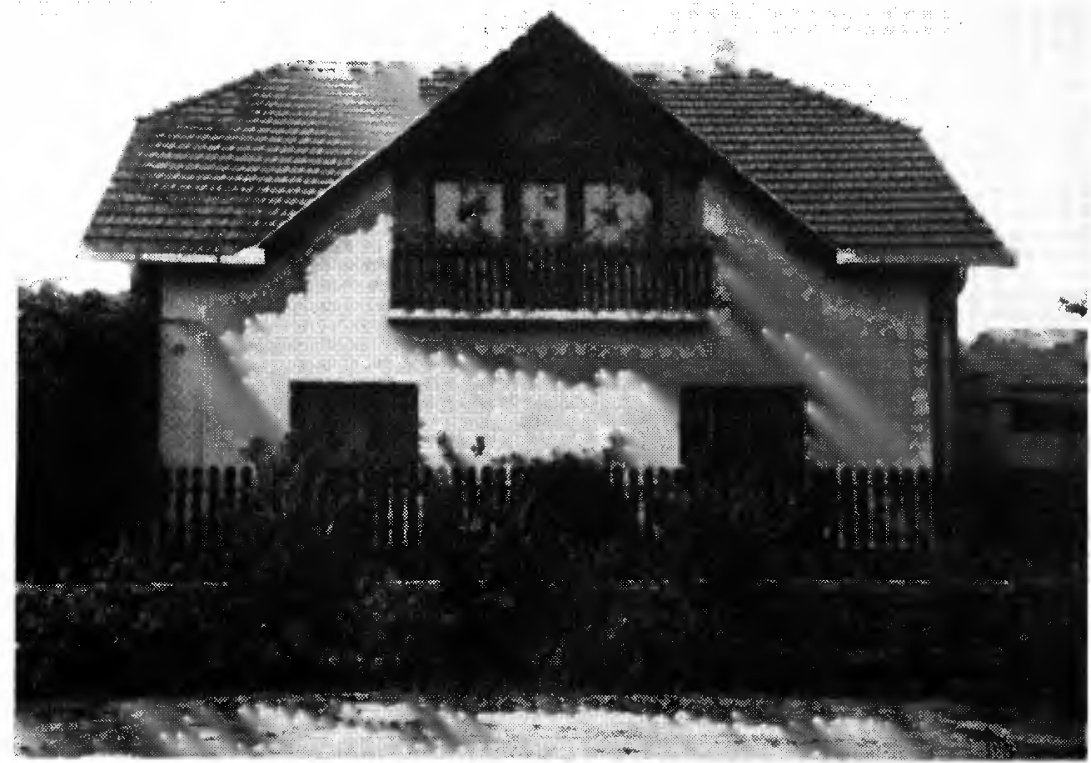

4. KÉP

,Modern napsugár” egy újonnan épült belterületi lakóház oromzatán (Zákányszék). 


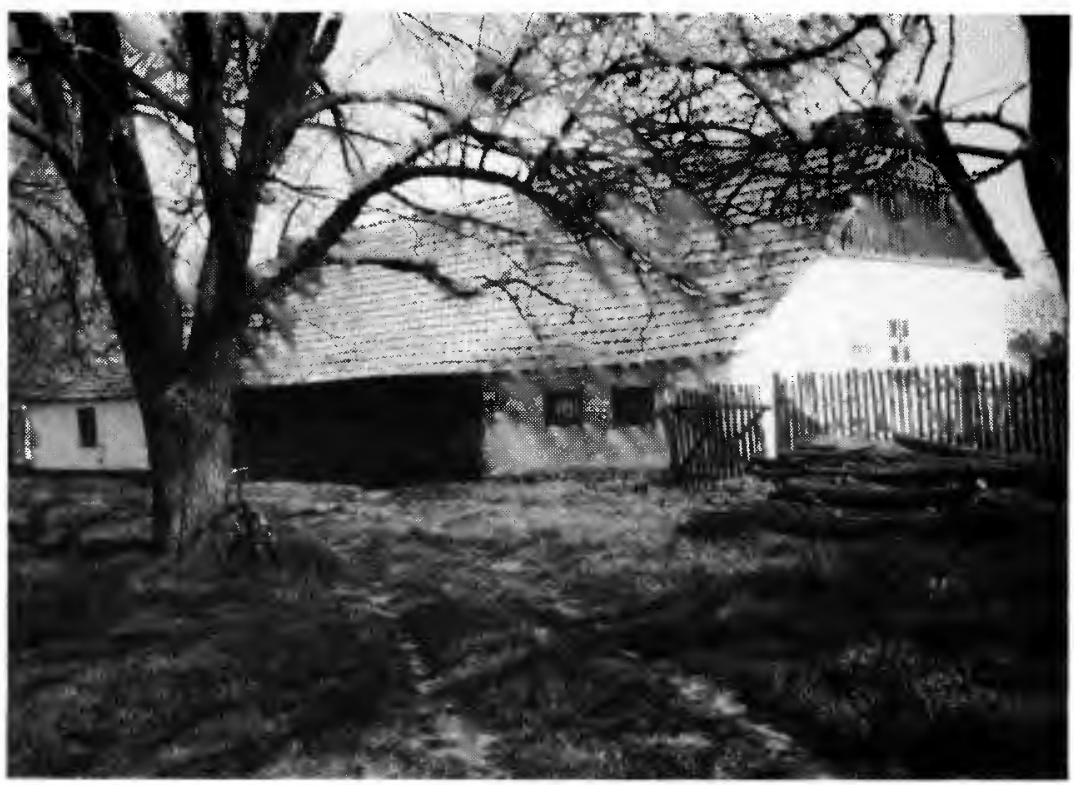

5. KÉP

Eredeti állapotában megmaradt ereszetes tanyaház a 19. századból. A födémcsere éve 1914 (Zákányszék).

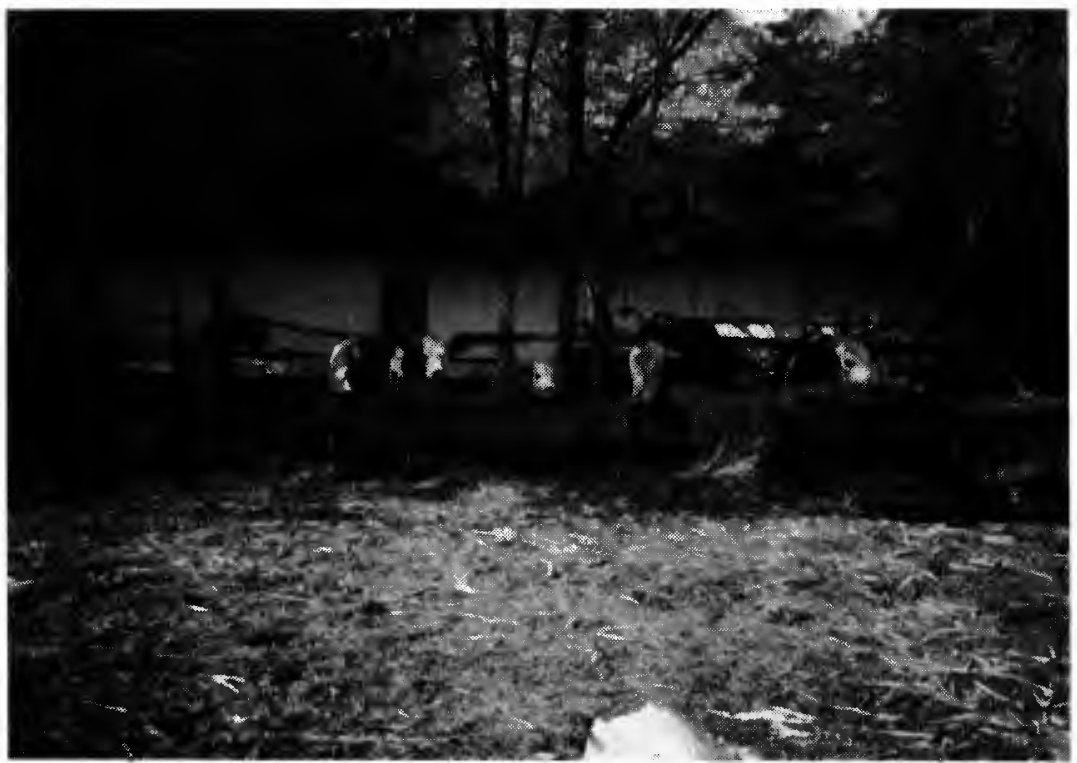

6. KÉP

Gazdálkodásra használt idôszakosan lakott tanya a faluközpont közelében (Zákányszék). 
A tanya és a zárt települések kapcsolata - társadalomföldrajzi megközelítésben.

Tér és Társadalom, 4. 1990. 2. 63-85. p.

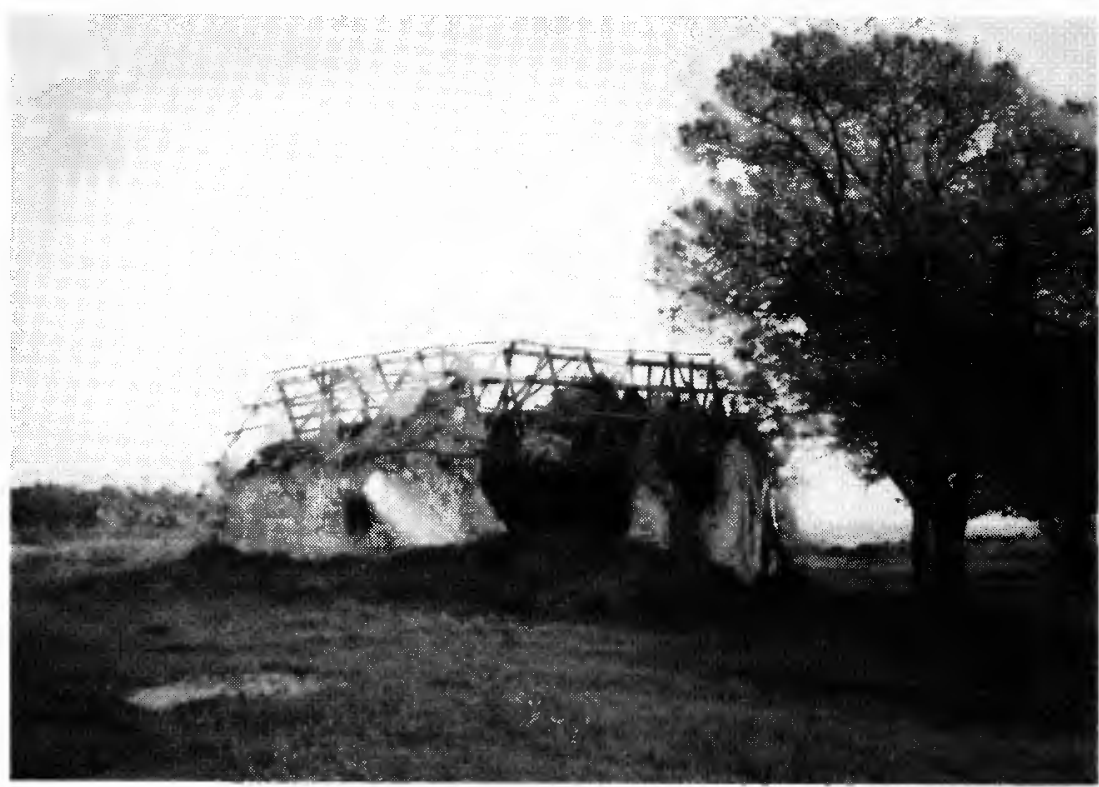

7. KÉP

Pusztulás - A természetes anyagokból épült tanyaház lassan eggyé válik a földdel (Zákányszék).

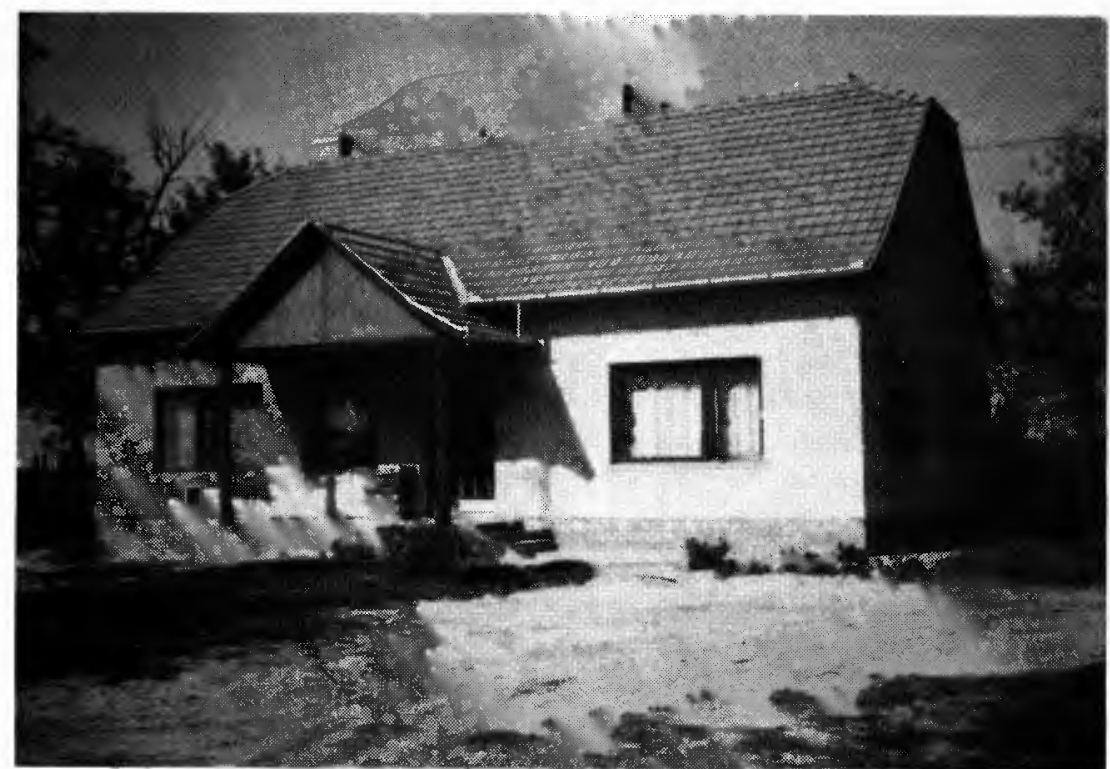

8. KÉP

Megújulás - Tanya a szülôi ház mellett (Zákányszék). 


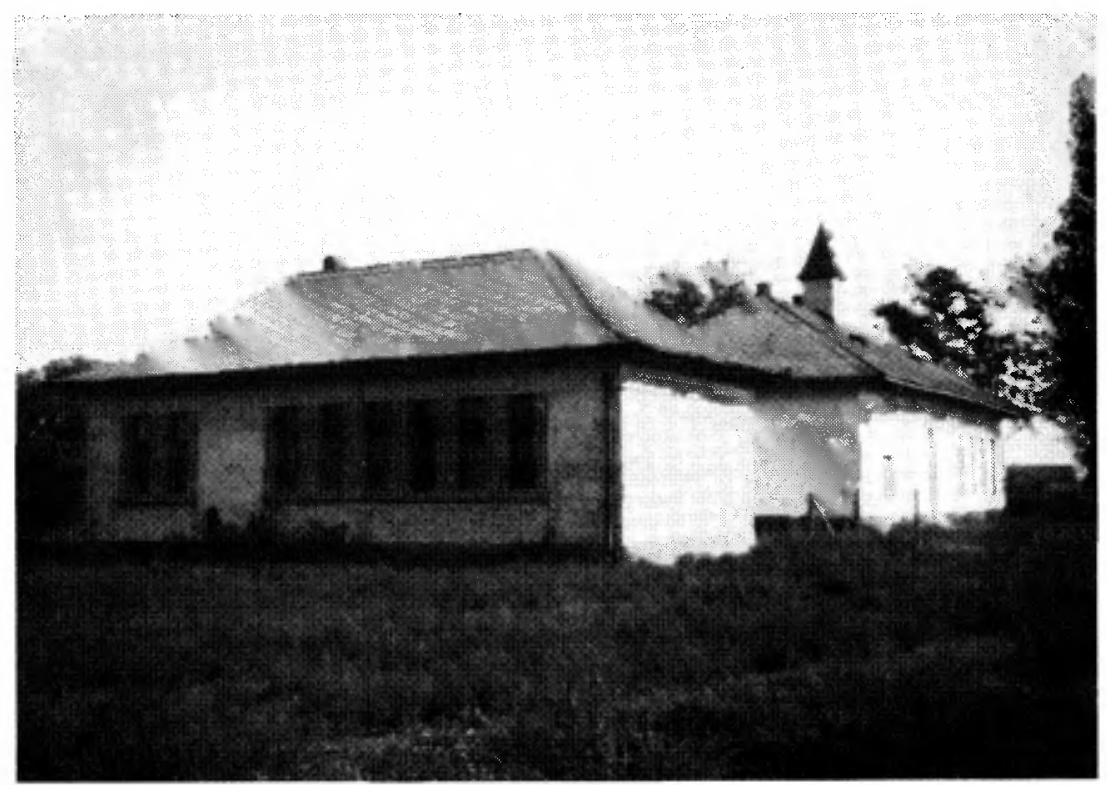

9. KÉP

A századelốn nem volt olyan pontja a szegedi határnak, ahonnan $3 \mathrm{~km}$-nél messzebb esett volna valamelyik tanyai iskola. Ezek azépületek ma is állnak, de tanítás már csak a belterületen folyik (Zákányszék-Alsó). 